\title{
Identification of peptide and protein doping related drug compounds confiscated in Denmark between 2007-2013
}

\author{
Rune Andersen Hartvig, Niels Bjerre Holm, Petur Weihe Dalsgaard, Lotte Ask Reitzel, \\ Irene Breum Müller, Kristian Linnet*
}

Section of Forensic Chemistry, Department of Forensic Medicine, Faculty of Health Sciences University of Copenhagen, Frederik V's Vej 11, 2100 Copenhagen, Denmark

*Corresponding Author: E-mail: kristian.linnet@sund.ku.dk

\begin{abstract}
We present an overview of protein and peptide compounds confiscated in Denmark from late 2007 till late 2013 together with a description of a newly developed HRAM-LC-MS method used for identification. As examples of identification, we present data for the peptides AOD-9604, [D-Ala ${ }^{2}, \mathrm{Gln}^{8}$, Ala ${ }^{15}$, Leu $\left.{ }^{27}\right]$ sermorelin and the protein follistatin. It was found that a method with minimum sample preparation could be implemented for all of the confiscated peptides and the protein somatropin. However, for the protein follistatin it was necessary to include trypsin digestion in the sample preparation, which considerably increases the overall analysis time.
\end{abstract}

Keywords:

Black market drugs, doping, screening, peptides, hormones, proteins, mass spectrometry, high-resolution MS

\section{ABBREVIATIONS}

LC - Liquid Chromatography,

HRAM-MS - High-Resolution Accurate Mass - Mass Spectrometry,

FWHM - Full Width Half Maximum

\section{INTRODUCTION}

In recent years the pharmaceutical industry has increased the number of proteins and peptides on the market and additional compounds are in research and development phases [1,2]. This development also influences the type of drugs found on the illegal market. Protein and peptide drugs, especially those relevant for doping in sports, are often confiscated, including compounds that are not available on the legal, pharmaceutical market [3]. This not only represents a problem in terms of cheating in sports but also constitutes a health issue, since the compounds are not guaranteed to be of pharmaceutical grade quality, and in many cases have not been licensed for human consumption, or have even failed clinical trials. An example of the latter is the peptide drug cjc-1295 [4], which was discontinued in phase II clinical trials following the death of a test person $[5,6]$, but is still advertised for sale on the black market.

The protein and peptide compounds confiscated in Denmark are usually identified by Danish customs or police as being doping related based on their visual appearance; injections vials containing either a powder or in some cases a liquid. Often the vials are labeled with a compound name, in which case the legal authorities often choose to not have the compound analyzed further. In other cases the vials are delivered to our department for identification. If the compound is not present in our in-house database, it is either analyzed further by us or forwarded to specialized doping control institutions in Norway or Germany and subsequently added to the database. The in-house database is continuously created using reference compounds.
The reference compounds are either from trusted manufactures or from confiscated compounds, which has been identified by other accredited institutions or by us as demonstrated in this paper for the compounds AOD9604 and follistatin.

To identify the compounds we employ two complimentary methods: i) First the compound is analyzed by HPLC-DAD and the retention time and UVprofile are compared to our internal database. ii) The compound is analyzed with HRAM-LC-MS for added certainty in the identification. For identification of peptides and proteins by HRAM-LC-MS we use a combination of accurate mass determination, retention time and characteristic product ions. This approach is based on the recommendations put forward by Thevis et al. for identification of peptides and proteins in doping control [7]. The aim of this paper is to describe the newly developed HRAM-LC-MS method and to present an overview of the compounds encountered by our forensic laboratory between 2007 and 2013.

\section{MATERIALS AND METHODS}

The confiscated injection vials all contained white powder material. The powders were dissolved in water to a final concentration of a few $\mathrm{mg} / \mathrm{ml}$. Water and acetonitrile used were both LC-MS grade (Fischer Scientific, UK). Formic acid was $98-100 \%$ (Merck KGaA, Germany).

\subsection{HPLC-DAD}

High-Performance Liquid Chromatography with Diode-Array Detection (HPLC-DAD) separation was performed on an YMC-Pack PROTEIN-RP column (YMC Europe $\mathrm{GmbH}$, Germany) held at a temperature of $30{ }^{\circ} \mathrm{C}$, with UV-detection at $210 \mathrm{~nm}$ (scan range 210-400 nm). The mobile phase was composed of solvents A (0.5\% TFA in mili-Q water), B (acetonitrile) and $\mathrm{C}$ (mili-Q water) the flow rate was $1.0 \mathrm{ml} / \mathrm{min}$ and an injection volume 
of $10 \mu \mathrm{L}$. The gradient was isocratic for 5 min at: (A: 20\%, B: 10\%, C: $70 \%$ ), increased to (A: $20 \%, B: 70 \%, C: 10 \%)$ during $35 \mathrm{~min}$, and was subsequently re-equilibrated for $5 \mathrm{~min}$.

\subsection{HRAM-LC-MS/MS}

In the HRAM-LC-MS/MS method chromatographic separation was performed on a Dionex Ultimate 3000 UHPLC system (Thermo Scientific, Germany) with

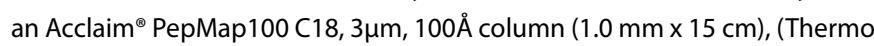
Scientific, US), which was maintained at a temperature of $40{ }^{\circ} \mathrm{C}$. The mobile phase was composed of solvents A (water containing $0.1 \%$ formic acid) and $B$ (acetonitrile and $0.1 \%$ formic acid) at a flow rate of $0.06 \mathrm{~mL} / \mathrm{min}$. The gradient had a total run-time of $30 \mathrm{~min}$ starting at $5 \% \mathrm{~B}$ increasing to 95 $\%$ B over $25 \mathrm{~min}$, isocratic for $2 \mathrm{~min}$ before re-equilibration for $3 \mathrm{~min}$. The injection volume was 5-10 $\mu \mathrm{L}$.

The LC was coupled to a Q-Exactive mass spectrometer (Thermo Scientific, Germany) using positive electrospray ionization, with a cone voltage of $4 \mathrm{kV}$ and capillary temperature of $200^{\circ} \mathrm{C}$. The data were acquired using data-dependent acquisition with MS/MS scans of the top 5 most abundant ions after each full scan. Full scan data were collected in profile mode from m/z 280-2000 at a resolution of 70,000 (FWHM @ m/z 200). Normalized collision energy of $20 \%$ was used to create the product ions, which were detected at a resolution of 35.000 . The Q-Exactive was externally calibrated in positive and negative mode twice a week using Pierce ${ }^{\oplus}$ ESI positive and negative calibration solutions (Thermo Scientific, US).

\subsubsection{Reduction of disulfide bonds and cysteine alkylation}

$0.5 \mathrm{mg}$ of protein or peptide powder was dissolved in $100 \mu \mathrm{l}$ buffer $(50 \mathrm{mM}$ ammonium bicarbonate). The disulfide bonds were then reduced by adding $10 \mu \mathrm{l} 100 \mathrm{mM}$ dithiothreitol solution (Sigma, US) and heated to $95^{\circ} \mathrm{C}$ for 15 $\mathrm{min}$. The reduced cysteine groups were subsequently alkylated by adding 10 $\mu$ l of freshly prepared iodoacetamide (Sigma, US) solution (200mM in water), and placed in the dark at room temperature for $30 \mathrm{~min}$.

\subsubsection{Trypsin treatment}

The solution of alkylated protein was then diluted with $500 \mu \mathrm{l}$ ammonium bicarbonate buffer before addition of $100 \mu \mathrm{l}(50 \mathrm{mM}$ acetic acid in water, $\mathrm{pH}$ 8) containing $2.5 \mu \mathrm{g}$ sequencing grade trypsin (Promega, US). The solution was incubated at $37^{\circ} \mathrm{C}$ for 16 hours. The trypsin to protein powder mass ratio was 1:200.

\section{RESULTS}

The peptide and protein drug substances confiscated by Danish customs and police in the period between late 2007 and late 2013 are presented in Table 1. The identified compounds totaled 6 different peptides (AOD9604, GHRP-2, GHRP-6, sermorelin, [D-Ala ${ }^{2}, \mathrm{Gln}^{8}$, Ala ${ }^{15}$, Leu ${ }^{27}$ ]sermorelin and melanotan II) and 4 proteins (somatropin, hCG, follistatin and IGF-1).

\section{1 AOD-9604}

AOD-9604 is a 16 amino acid fragment of the C-terminus of the growth hormone protein Somatropin. It has a monoisotopic molecular mass of 1813.8604 Da, and the amino acid sequence: YLRIVQCRSVEGSCGF with a disulfide bridge between the cysteines at position 7 and 14 (see Figure 1). The disulfide bond can be reduced with DTT and the reduced cysteine groups alkylated with iodoacetamide to prevent reformation of the disulfide bonds, giving a monoisotopic weight of alkylated AOD-9604 of 1929.9189 Da.

The first criteria for successful identification of AOD-9604 is the observation of the precursor ions corresponding to the mass $1813.8604 \mathrm{Da}$

Table 1. Substances identified in confiscated products by our department during the period 2007-2013.

\begin{tabular}{|c|c|c|c|c|c|c|c|}
\hline \multirow[b]{3}{*}{ Compounds } & \multicolumn{7}{|c|}{ Year } \\
\hline & $2007^{1}$ & 2008 & 2009 & 2010 & 2011 & 2012 & $2013^{1}$ \\
\hline & \multicolumn{7}{|c|}{ Number of confiscation cases } \\
\hline AOD-9604 & & & & & & & 1 \\
\hline GHRP-2 & & & & & 2 & 2 & \\
\hline GHRP-6 & & & & & 3 & 1 & \\
\hline Sermorelin & & & & & 1 & 1 & 3 \\
\hline$\left[\mathrm{D}-\mathrm{Ala}^{2}, \mathrm{Gln}^{8}, \mathrm{Ala}^{15}\right.$, & & & & & 7 & 2 & 1 \\
\hline \multicolumn{8}{|l|}{ Leu $\left.^{27}\right]$ Sermorelin } \\
\hline Melanotan II & & & 3 & 1 & 6 & 1 & \\
\hline Follistatin & & & & & & & 1 \\
\hline Somatropin & 2 & 2 & 7 & 7 & & 2 & 1 \\
\hline hCG & & 1 & 2 & 2 & 3 & 1 & 1 \\
\hline IGF-1 & & 1 & & $1^{2}$ & & & \\
\hline Negatives & 1 & 1 & & 2 & 4 & 4 & $3^{3}$ \\
\hline \multicolumn{8}{|c|}{ 'From late 2007 and first half of 2013, respectively } \\
\hline \multicolumn{8}{|c|}{${ }^{2}$ Presumed to be IGF-1 from the original label and from initial HPLC-DAD analysis, but later found to be negative } \\
\hline In one of the case & he la & tain & & & & & \\
\hline
\end{tabular}


and 1929.9189 Da for the untreated and alkylated peptide, respectively. In the MS spectra of both alkylated and non-alkylated AOD-9604, two charge states are observed (see inserts in Figure $\mathbf{2}$ and $\mathbf{3}$ ) that both correspond to the expected mass of the peptide. The second criteria is the observation of the expected product ions from fragmentation: The MS/MS of the double charged AOD-9604 ions produces the product ions seen in Figure $\mathbf{2}$ and $\mathbf{3}$.

\section{2 [D-Ala $\left.{ }^{2}, \mathrm{Gln}^{8}, \mathrm{Ala}^{15}{ }^{15} \mathrm{Leu}^{27}\right]$ sermorelin}

The amino acid sequence of this sermorelin analogue is YADAIFTQSYRKVLAQLSARKLLQDILSR-NH , $_{2}$ where the second alanine,
$\mathrm{Ala}^{2}$, is the non-natural D-isomer. This peptide was identified by its retention time and UV-spectrum on the HPLC-DAD method and from its characteristic precursor and product ions on the HRAM-LC-MS. [D-Ala ${ }^{2}$, $\mathrm{Gln}^{8}$, $\mathrm{Ala}^{15}$, Leu $\left.{ }^{27}\right]$ sermorelin has a calculated monoisotopic weight of 3365.8936 Da and 6 chargeable groups ( 3 arginine and 2 lysine amino acids, plus the amino group at $\mathrm{N}$-terminal). A primary identification criterium is therefore the presence of at least some of the ions corresponding to the 6 positively charged species: $[\mathrm{M}+\mathrm{H}]^{1+}$ to $[\mathrm{M}+6 \mathrm{H}]^{6+}$ (see Figure 4). Secondly, the observed precursor ions are fragmented to produce characteristic product ions for further identification (see Figure $\mathbf{5}$ and $\mathbf{6}$ ).
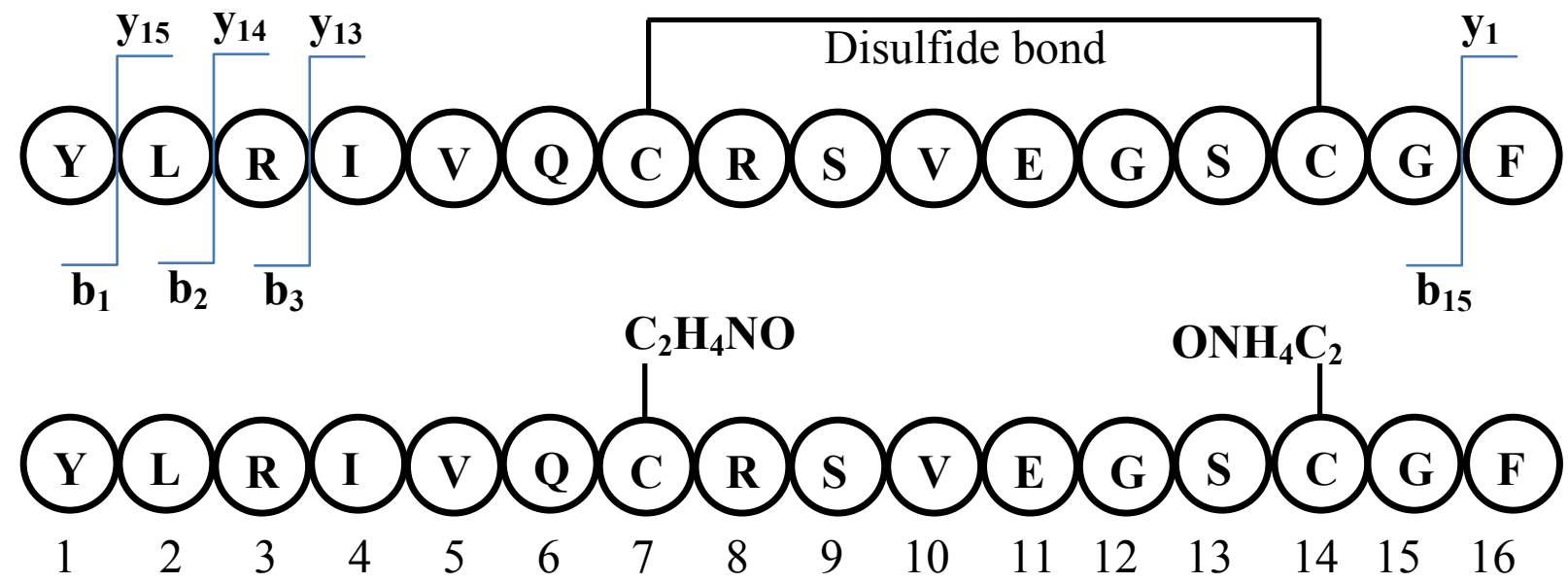

Figure 1. (Top) Structure of AOD-9604 with examples of b- and y-ions. (Bottom) AOD-9604 after reduction of disulfide bond and alkylation of cysteine.

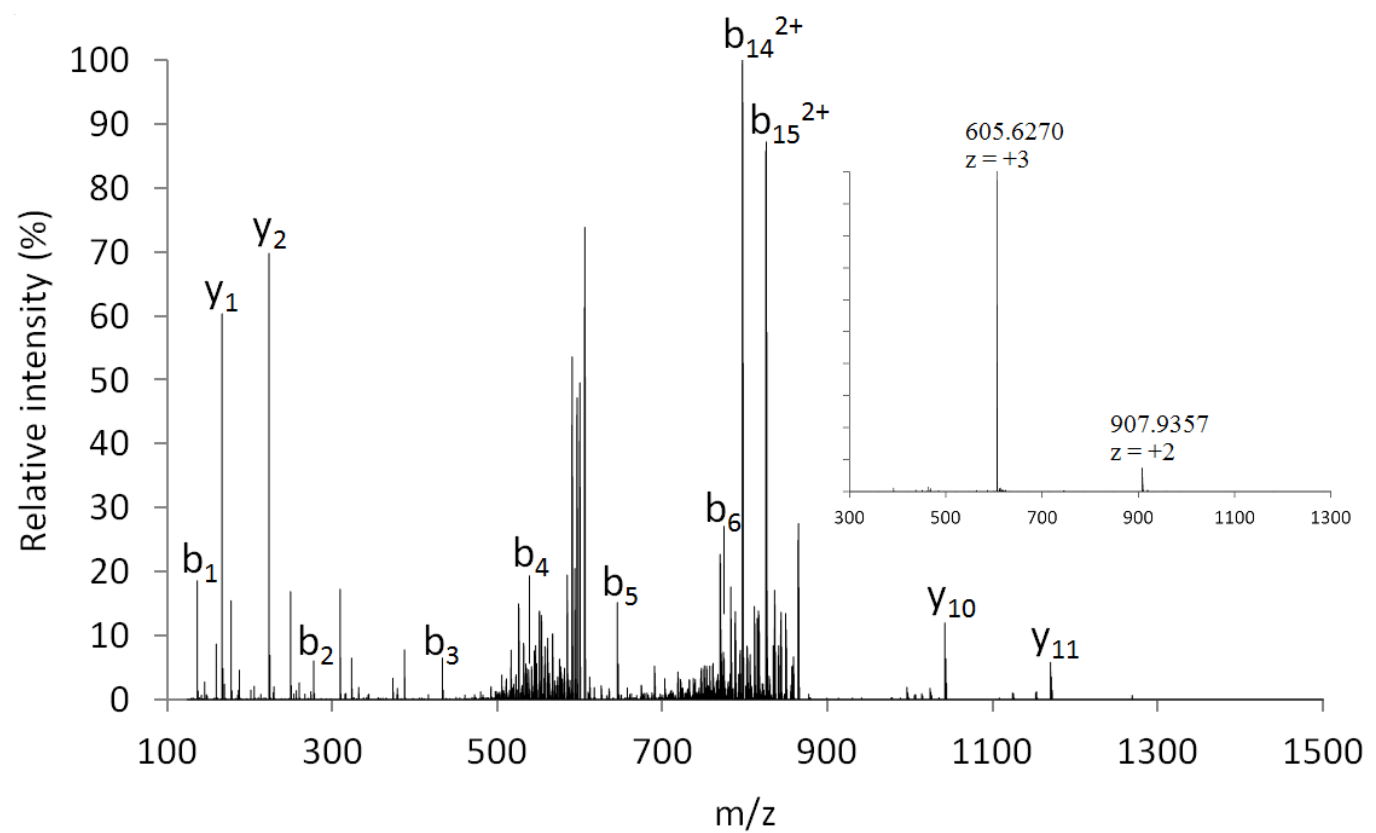

Figure 2. AOD-9604. Product ions of the precursor at $605.627 \mathrm{~m} / \mathrm{z}$. Insert: Full scan mass spectrum of AOD-9604. Masses are for the monoisotopic molecules. 


\section{Scher}

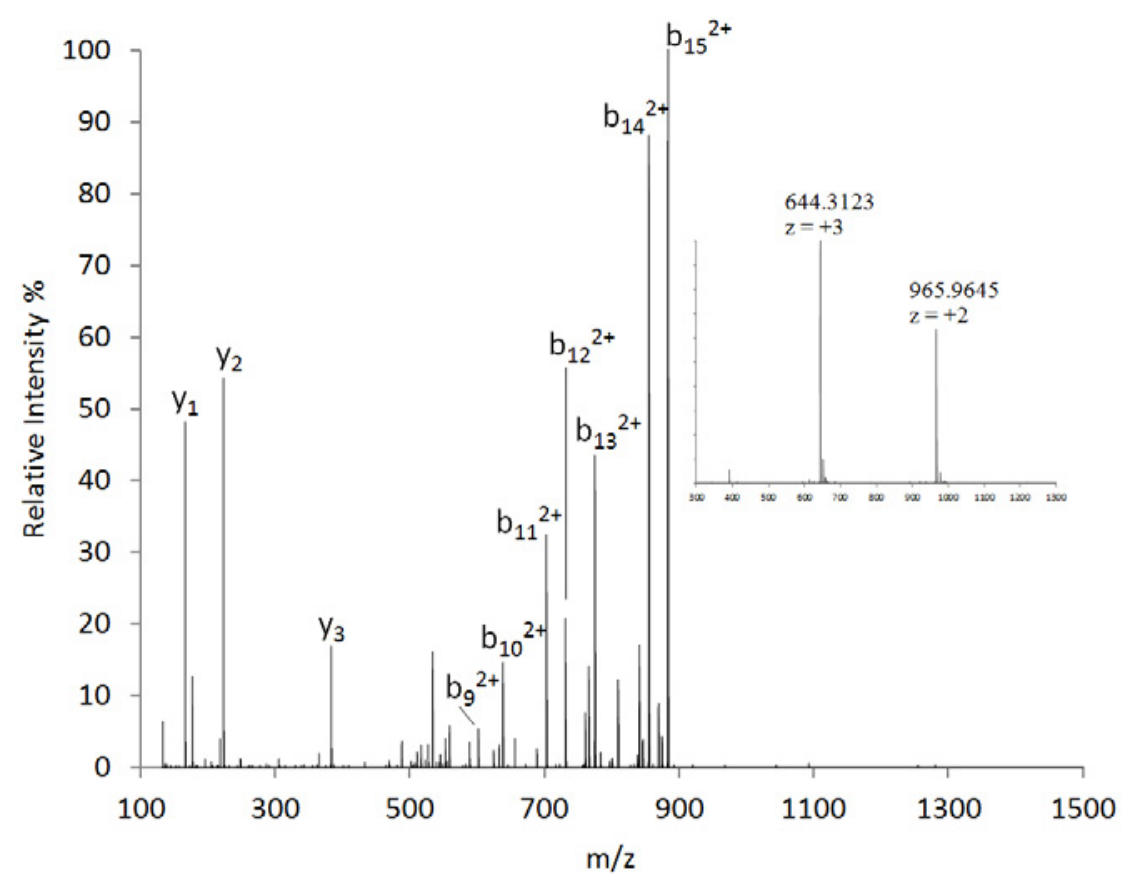

Figure 3. Mass spectrum of alkylated AOD-9604 product ions (precursor $644.3 \mathrm{~m} / \mathrm{z}$ ). The $b$-ions $\mathrm{b}_{8}{ }^{2+}$ to $\mathrm{b}_{13}{ }^{2+}$ is only observed in the treated AOD-9604 since the disulfide bond has been reduced and alkylated. Insert: Full scan mass spectrum of alkylated AOD-9604. Masses are for the monoisotopic molecules.

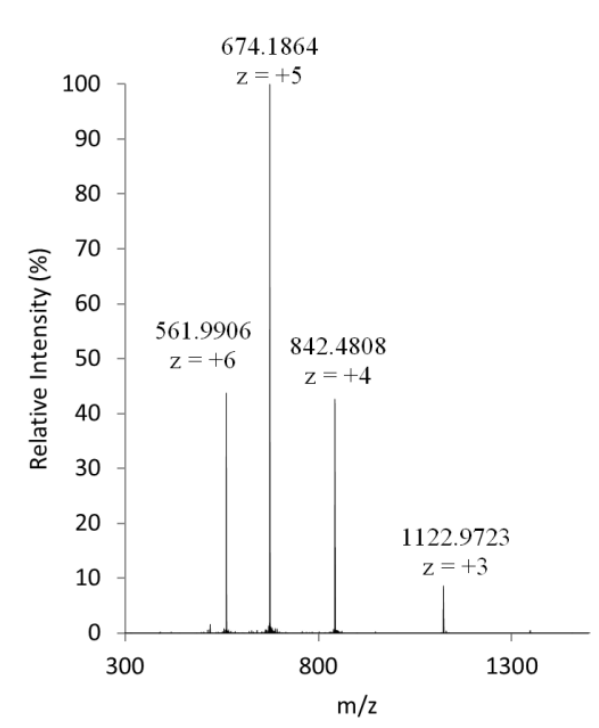

Figure 4. Mass spectrum of $\left[\mathrm{D}-\mathrm{Ala}^{2}, \mathrm{Gln}^{8}, \mathrm{Ala}^{15}\right.$, $\left.\mathrm{Leu}^{27}\right]$ Sermorelin precursor ions. Masses are for the monoisotopic molecules.

\subsection{Follistatin}

A confiscated injection vial labeled as follistatin was investigated by HRAMLC-MS. No peptides or proteins were initially detected in the untreated sample, which was therefore reduced, alkylated and treated with trypsin before it was re-analyzed. The chromatogram now revealed several smaller peptides indicating that a protein had been present. Based on the label,

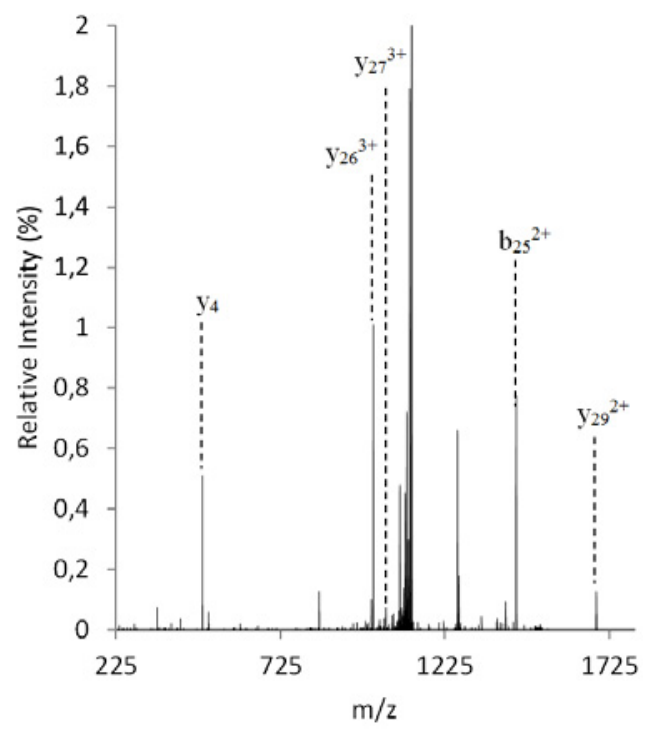

Figure 5. MS/MS product ions of [D-Ala ${ }^{2}, \mathrm{Gln}^{8}, \mathrm{Ala}^{15}$, $\left.\mathrm{Leu}^{27}\right]$ Sermorelin (precursor $1122.97 \mathrm{~m} / \mathrm{z})$.

the amino acid sequence of both follistatin-288 and follistatin-315 were examined for trypsin cleavage sites. Since trypsin cleaves the polypeptide chain at specific sites (after arginine and lysine, if either is not followed directly by proline) the expected peptides can be predicted (see the tryptic peptides in Figure 7). Since arginine and lysine are both positively charged amino acids, most peptides will be double charged ions $[\mathrm{M}+2 \mathrm{H}]^{+2}$. 


\section{DISCUSSION}

The detection and identification of peptides and proteins is an interdisciplinary field. In proteomics the challenge is usually to identify hundreds or thousands of different proteins in a mixture at low concentrations, a process in which the mix of proteins is digested to form smaller peptides that are then analyzed against huge databases. In doping control, the task is to identify one or more peptides or proteins in a biological matrix. In contrast, confiscated drugs are usually in a relatively pure state, though some examples of mixtures are encountered, e.g. doping related peptides found in nutritional supplements [3], and confiscated vials containing more than one drug compound.

Examples of LC-MS characterization of doping peptides and proteins: GHRP-2 [3,9,10], GHRP-6 [10], sermorelin [11], [D-Ala ${ }^{2}, \mathrm{Gln}^{8}, \mathrm{Ala}^{15}$, $\mathrm{Leu}^{27}$ ] sermorelin [12], melanotan II [13-15], IGF-1 [16-19], hCG [20,21] and somatropin $[11,19]$. Mass spectrometry data for identification of AOD-9604 and follistatin has to our knowledge not previously been published in the literature and is therefore presented here. Identification of [D-Ala ${ }^{2}, \mathrm{Gln}^{8}, \mathrm{Ala}^{15}$, Leu $^{27}$ ]sermorelin using LC-MS/MS was recently published [12], but here we identify this peptide without prior treatment with trypsin.

With the HPLC-DAD method all of the above compounds are detectable, though the larger proteins have to be flushed from the column with an organic:aqueous phase ratio of 80:20. On the HRAM-LC-MS method all the above peptides and somatropin where directly detectable. As there were no recent samples of IGF-1 and hCG available at the time, these were not tested on the HRAM-LC-MS method.

Follistatin had to be enzymatically digested into smaller peptides before being observable on the MS. This could have a number of explanations. Many proteins, especially large proteins with a low structural stability, adsorb strongly and practically irreversible on most surfaces. Therefore the amount of protein that elutes from the column is severely limited. Furthermore, large molecules are a lot less likely to turn into gas form in the electrospray interface [8].

For peptides at low collision energies, as used in these experiments, the observed MS/MS fragments mostly correspond to a break of the peptide backbone at the bond between the carbonyl carbon and the amine nitrogen. The fragment on the $\mathrm{N}$-terminal is designated as the b-ion and the fragment on the $\mathrm{C}$-terminal side of the cleavage is the $\mathrm{y}$-ion according to nomenclature. This is depicted with AOD-9604 as an example in Figure 1.

\subsection{AOD-9604}

This peptide was initially developed as an anti-obesity drug and was recently the focus of a large doping scandal in Australian Rules football. It is not licensed for pharmaceutical distribution, but products using the name is marketed and sold online as a fat-burning and muscle building drug.

The disulfide bond in the molecule prevents the formation of identifiable ions between position 7 and 14 in the chain. For example a break of the peptide bond between \#8-9 would have the same $\mathrm{m} / \mathrm{z}$ as that between e.g. \#9-10 (see Figure 1). Because AOD-9604 was not in our database and because detailed mass spectral data has not been previously published, we decided to do a more thorough identification to include identifying ions between these positions. This is done by reducing the disulfide bond and alkylating the reduced cysteine side-group.

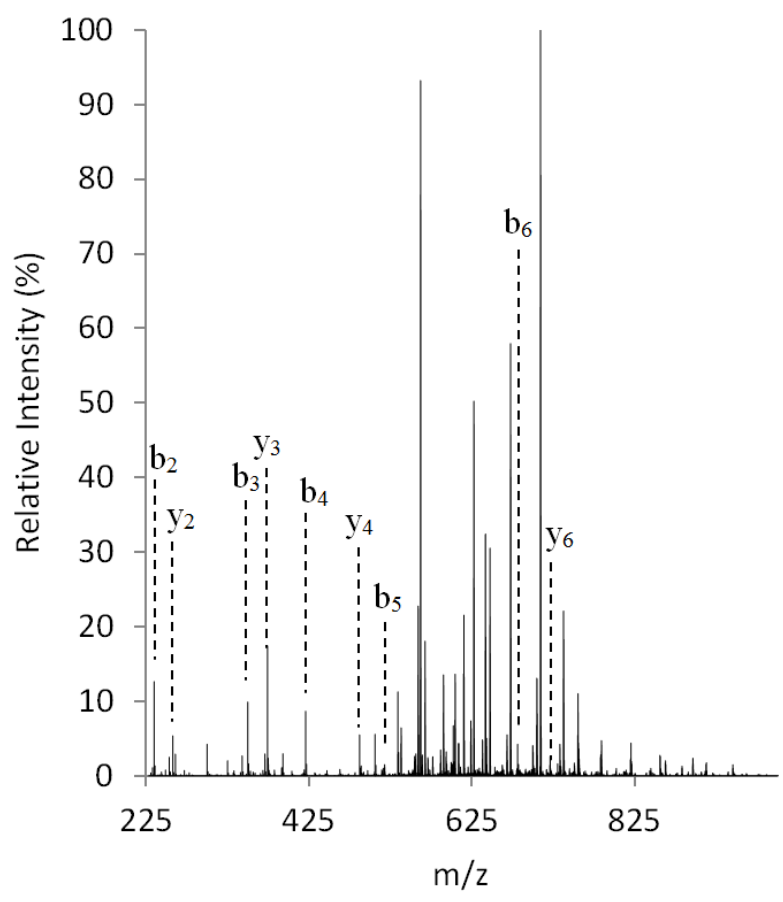

Figure 6. MS/MS product ions of [D-Ala ${ }^{2}, \mathrm{Gln}^{8}, \mathrm{Ala}^{15}$, Leu $\left.{ }^{27}\right]$ Sermorelin (precursor $561.99 \mathrm{~m} / \mathrm{z}$ ).

Both the alkylated and non-alkylated samples produce species with two and three charges (Figure 2 and 3). These three charges most likely reside on the $\mathrm{N}$-terminal amino-group and the arginine amino acids at position 3 and 8 , as they are the most ionizable groups of the molecule. In the MS/MS spectrum of alkylated AOD-9604 a range of b- and y-ions are formed that are not observed in the untreated AOD-9604 (Figure 3). This demonstrates that the compound was indeed AOD-9604 linked with an internal disulfide bond. To minimize preparation time in the future, our identification will be based on the precursor and product ions from the untreated, non-alkylated peptide. This identification is done from molecular weight determination from the two precursor ions and structural identification from a total of 12 product ions with assignment as seen in Table 2.

\section{2 [D-Ala ${ }^{2}$, Gln $^{8}$, Ala $^{15}$, Leu $\left.^{27}\right]$ Sermorelin}

In 2005 the Canadian company ConjuChem published a number of modified versions of the growth-releasing-factor peptide sermorelin, named CJC-1288, CJC-1293 and CJC-1295 [4]. These modifications all included the addition of a lysine at the C-terminus linked to a chemical group named "Drug Affinity Construct" (DAC) by the company [4]. These peptide drugs are no longer in the pipeline at ConjuChem, but compounds using these names can be bought online from other sources. However, these products have mostly been found by our laboratory and others [12] to contain sermorelin or the modified sermorelin lacking the lysine-linker and DAC-group, a peptide for which the IUPAC name would be [D-Ala ${ }^{2}, \mathrm{Gln}^{8}, \mathrm{Ala}^{15}$, $\mathrm{Leu}^{27}$ ]sermorelin.

$\left[D-\mathrm{Ala}^{2}, \mathrm{Gln}^{8}, \mathrm{Ala}^{15}, \mathrm{Leu}^{27}\right.$ ]sermorelin was identified from the molecular weight calculated from precursor ions and from structural information from product ions, as seen in Table 3. 


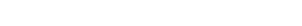

It is an interesting observation that for most of the peptides and proteins the fragmentation pattern is very dependent on the choice of precursor ion. For example compare the product ions of [D-Ala ${ }^{2}, \mathrm{Gln}^{8}, \mathrm{Ala}^{15}$, Leu $^{27}$ ]sermorelin having +3 and +6 charges (Figures 5 and 6). The most apparent difference is that for the low charge, the fragments have a lot lower abundance (notice the scale of the $y$-axis). The most abundant ion here is the unfragmented precursor ion itself at $\mathrm{m} / \mathrm{z} 1122.97$ and the most abundant fragment is only $1 \%$. In contrast, the MS/MS from the +6 precursor $(\mathrm{m} / \mathrm{z}$ 561.99) is much more fragmented and fragments have higher relative intensities. As seen by comparison of Figures 5 and $\mathbf{6}$ the precursor ion with more charges produces more and smaller fragments. On the contrary, many of the larger b- and y-ions can be detected in the MS/MS of the low charge precursor. Analytically this has the advantage that a larger range of product ions can be detected. Thus we generally base identification on a range of precursor ions (see for example Table 3 ).

\subsection{Follistatin}

Follistatin exists in two isoforms of either 288 amino acids or 315 amino acids, which can be post-translationally N-glycosylated at positions Asn95 and Asn259. There seems to be little focus on follistatin in the academic doping and forensic literature, but the product is widely sold on the internet and is especially advertised for body building.

Follistatin was identified by detection of peptide fragments after treatment with trypsin. The observed peptides cover at least $85 \%$ of the total sequence. The parts of the sequence that are not covered consist of the very small tryptic peptides, 1-3 amino acid length, and the C-terminal peptide (T41 in Figure 7). Follistatin has a high frequency of arginine and lysine amino acids, resulting in many cleavages and small peptides that are difficult to separate on the column and identify. To distinguish between follistatin-288 and -315 the C-terminal peptide would be detected as either a sequence of length 6 or 33, respectively. While one should expect to detect the follistatin-288 C-terminal the follistatin-315 C-terminal peptide is a very long sequence and does not contain an arginine or lysine in the end. A low charge and a long sequence make this peptide unlikely to be efficiently ionized and thus detected with MS [8]. This suggests that the protein was follistatin-315, though further analysis would be needed to conclusively distinguish it from follistatin-288. The tryptic peptides containing position 95 (peptide T16) and position 259 (peptide T39) where both detected at the mass expected from their amino acid sequence, suggesting that none of the $\mathrm{N}$-glycosylation sites were glycosylated. The lack of glycosylation suggests that the compound is a recombinant follistatin that has been expressed in a bacterial cell culture.

\subsection{Confiscated drugs}

We note that the original labels on the confiscated products do not necessarily correspond with the actual substance found from analysis. So far, all of the products sold under the names cjc-1295 and cjc-1293 contained

Table 2. Identification of AOD-9604 by HRAM-LC-MS/MS. Two precursor ions are observed at $\mathrm{m} / \mathrm{z} 907.9357$ and $\mathrm{m} / \mathrm{z} 605.6270$, respectively. Each produces fragment ions, which are used for further certainty in the identification. Masses are for the monoisotopic molecules.

\begin{tabular}{|c|c|c|c|c|}
\hline \multirow{3}{*}{$\begin{array}{c}\text { Fragment ions } \\
\text { Fragment ion } 1(\mathrm{~m} / \mathrm{z})\end{array}$} & \multicolumn{4}{|c|}{ Precursor ions } \\
\hline & \multicolumn{2}{|c|}{$(M+2) m / z 907.9357$} & \multicolumn{2}{|c|}{$\begin{array}{c}(M+3) \mathrm{m} / \mathrm{z} \\
605.6270\end{array}$} \\
\hline & 136.076 & $b_{1}$ - immonium ion & 796.889 & $\mathrm{~b}_{14}{ }^{2+}$ \\
\hline Fragment ion $2(\mathrm{~m} / \mathrm{z})$ & 277.155 & $b_{2}$ & 825.399 & $\mathrm{~b}_{15}{ }^{2+}$ \\
\hline Fragment ion $3(\mathrm{~m} / \mathrm{z})$ & 433.256 & $b_{3}$ & & \\
\hline Fragment ion $4(\mathrm{~m} / \mathrm{z})$ & 546.340 & $\mathrm{~b}_{4}$ & & \\
\hline Fragment ion $5(\mathrm{~m} / \mathrm{z})$ & 645.409 & $b_{5}$ & & \\
\hline Fragment ion $6(\mathrm{~m} / \mathrm{z})$ & 773.467 & $b_{6}$ & & \\
\hline Fragment ion $7(\mathrm{~m} / \mathrm{z})$ & 166.087 & $y_{1}$ & & \\
\hline Fragment ion 8 (m/z) & 223.108 & $y_{2}$ & & \\
\hline Fragment ion $9(\mathrm{~m} / \mathrm{z})$ & 1042.409 & $y_{10}$ & & \\
\hline Fragment ion $10(\mathrm{~m} / \mathrm{z})$ & 1170.467 & $y_{11}$ & & \\
\hline $\mathrm{MW}(\mathrm{Da})$ & & 1813.86 & & \\
\hline
\end{tabular}

Table 3. Identification of [D-Ala ${ }^{2}, \mathrm{Gln}^{8}$, Ala ${ }^{15}$, Leu $\left.{ }^{27}\right]$ Sermorelin by HRAM-LC-MS/MS. A total of four different precursor ions are used. Product ions of these precursors are detected for further certainty in the identification. Masses are for the monoisotopic molecules.

\begin{tabular}{|c|c|c|c|c|c|c|c|c|}
\hline \multirow{3}{*}{$\begin{array}{c}\text { Fragment ions } \\
\text { Fragment ion } 1(\mathrm{~m} / \mathrm{z})\end{array}$} & \multicolumn{8}{|c|}{ Precursor ions } \\
\hline & \multicolumn{2}{|c|}{$(\mathrm{M}+3) \mathrm{m} / \mathrm{z} 1122.97$} & \multicolumn{2}{|c|}{$(M+4) m / z 842.48$} & \multicolumn{2}{|c|}{$(M+5) m / z 674.19$} & \multicolumn{2}{|c|}{$(M+6) m / z 561.99$} \\
\hline & 1068.615 & $y_{28}^{3+}$ & 699.931 & $y_{12}^{2+}$ & 235.108 & $b_{2}$ & 235.108 & $b_{2}$ \\
\hline Fragment ion $2(\mathrm{~m} / \mathrm{z})$ & 1044.939 & $y_{27}^{3+}$ & 856.021 & $y_{15}^{2+}$ & 350.135 & $b_{3}$ & 350.135 & $b_{3}$ \\
\hline Fragment ion $3(\mathrm{~m} / \mathrm{z})$ & 1006.591 & $\mathrm{y}_{26}{ }^{2+}$ & 962.097 & $y_{17}^{2+}$ & 421.172 & $\mathrm{~b}_{4}$ & 421.172 & $\mathrm{~b}_{4}$ \\
\hline Fragment ion $4(\mathrm{~m} / \mathrm{z})$ & 487.336 & $y_{4}$ & 819.831 & $y_{21}^{3+}$ & 534.256 & $b_{5}$ & 534.256 & $b_{5}$ \\
\hline Fragment ion 5 (m/z) & 1440.7907 & $\mathrm{~b}_{25}^{2+}$ & 896.200 & $y_{23}^{3+}$ & 681.325 & $\mathrm{~b}_{6}$ & 681.325 & $b_{6}$ \\
\hline Fragment ion $6(\mathrm{~m} / \mathrm{z})$ & & & 945.223 & $y_{24}^{3+}$ & 374.252 & $y_{3}$ & 261.168 & $y_{2}$ \\
\hline Fragment ion 7 (m/z) & & & 982.918 & $y_{25}^{3+}$ & 487.336 & $y_{4}$ & 374.252 & $y_{3}$ \\
\hline Fragment ion 8 (m/z) & & & 1006.597 & $y_{26}^{3+}$ & 602.363 & $y_{5}$ & 487.336 & $y_{4}$ \\
\hline Fragment ion $9(\mathrm{~m} / \mathrm{z})$ & & & 1044.939 & $y_{27}^{3+}$ & 956.589 & $\mathrm{y}_{8}$ & & \\
\hline Fragment ion $10(\mathrm{~m} / \mathrm{z})$ & & & 1068.618 & $y_{28}^{3+}$ & 1084.684 & $y_{9}$ & & \\
\hline MW (Da) & & & & & & & & \\
\hline
\end{tabular}




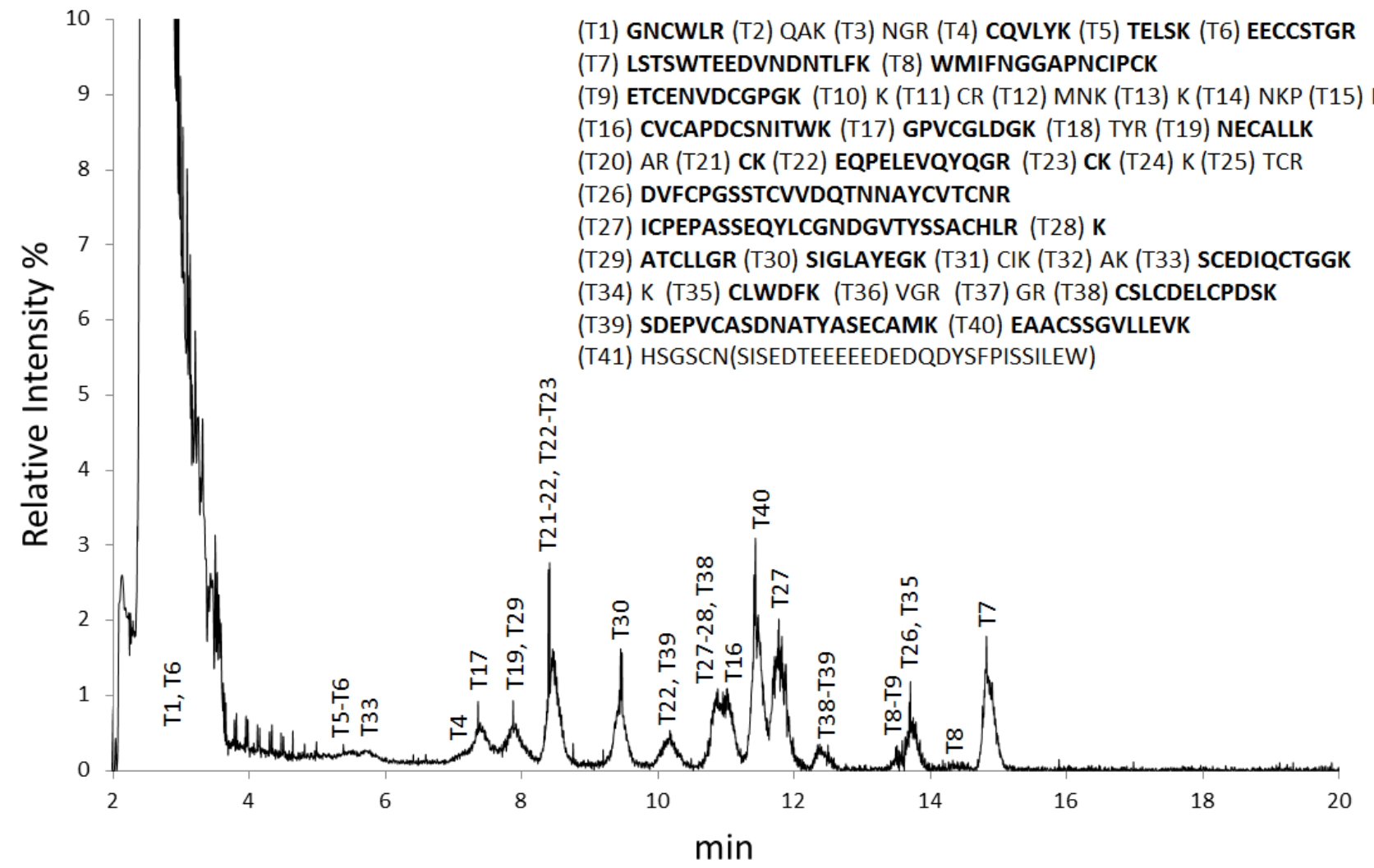

Figure 7. Chromatogram of tryptic peptides of Follistatin. Each expected tryptic digest is labelled with a " $\mathrm{T}$ " followed by its number in the sequence, peptides in bold letters were identified by mass. Because of missed trypsin cleavage sites some peptides are also found as a combination of two expected digests, e.g. T5-T6 is the sequence TELSK-EECCSTGR (where"-" shows the missed cleavage site)

sermorelin or the tetra substituted analogue $\left[\mathrm{D}-\mathrm{Ala}^{2}, \mathrm{Gln}^{8}, \mathrm{Ala}^{15}, \mathrm{Leu}^{27}\right]$ sermorelin. In some cases the products do not appear to contain any drug substance or contain an undetectable level of drug.

It is a noticeable trend (Table 1) that from the year 2011 and onwards, a number of new doping agents appear: AOD-9604, GHRP-2, GHRP-6, sermorelin, [D-Ala $\left.{ }^{2}, \mathrm{Gln}^{8}, \mathrm{Ala}^{15}, \mathrm{Leu}^{27}\right]$ sermorelin and follistatin. This is probably due to the fact that from 2010 Danish customs decided to increase their focus on the import of doping related drugs. Indeed, since late 2010 by far most of the seizures are confiscated by the customs, not the police. Another common denominator between these compounds is their presence on the internet on body building forums and advertising. It would seem that the new focus from Danish customs has revealed that a large amount of drugs are bought on the internet. Since the $1^{\text {st }}$ of January 2014 the penalty for doping offenses in Denmark increased from two to six years, which equates Danish law with the law of the surrounding countries [22]. This also expands the range of possible measures for the police to investigate and intervene in such cases, possibly leading to more cases in the future.

\section{CONCLUSION}

In conclusion a HRAM-LC-MS method was developed which, with minimum sample preparation, could identify all encountered peptide compounds and the protein somatropin, using precursor ions and fragments. It was not possible to identify the protein follistatin with this method, therefore a different approach using trypsin digestion and subsequent identification of characteristic tryptic peptides was used. These methods supplement our HPLC-DAD method in identifying confiscated peptides and proteins using a database, and can be used to identify compounds unknown to the database as demonstrated with the small peptide AOD-9604 and the protein follistatin.

Furthermore, the presented overview of drug cases between 2007 and 2013 reveals that the efforts from Danish customs since 2010 has exposed drug compounds not previously encountered by our laboratory. Presumably these compounds are often bought on the internet.

\section{REFERENCES}

[1] Vlieghe P., Lisowski, V., Martinez, J., Khrestchatisky, M., Synthetic therapeutic peptides: science and market, Drug Discovery Today., 2010, 15, 40-56
[2] Lawrence S., Biotech blockbusters consolidate markets, Nat.Biotechnol., 2006, 24, 1466 
[3] Kohler M., Thomas, A., Geyer, H., Petrou, M., Schänzer, W., Thevis, M., Confiscated black market products and nutritional supplements with non-approved ingredients analyzed in the cologne doping control laboratory 2009, Drug Test Analysis., 2010, 2, 533-537

[4] Jetté L., Léger, R., Thibaudeau, K., Benquet, C., Robitaille, M., Pellerin, I.et al., Human Growth Hormone-Releasing Factor (hGRF) ${ }_{1-29}$-Albumin Bioconjugates Activate the GRF Receptor on the Anterior Pituitary in Rats: Identification of CJC-1295 as a Long-Lasting GRF Analog, Endocrinology., 2005, 146, 3052-3058

[5] Patient Died in Lipodystrophy Drug Study, http://www.natap.org/2006/newsUpdates/081106_02.htm

[6] A Study to Evaluate CJC 1295 in HIV Patients With Visceral Obesity, http://clinicaltrials.gov/ct2/show/NCT00267527

[7] Thevis M., Loo, J. A., Loo, R. R. O., Schänzer, W., Recommended criteria for the mass spectrometric identification of target peptides and proteins $(<\mathrm{kDa})$ in sports drug testing, Rapid Commun.Mass Spectrom., 2007, 21, 297-304

[8] Mallick P., Schirle, M., Chen, S. S., Flory, M. R., Lee, H., Martin, D.et al., Computational prediction of proteotypic peptides for quantitative proteomics, Nat.Biotechnol., 2007, 25, 125-131

[9] Thomas A., Kohler, M., Mester, J., Geyer, H., Schanzer, W., Petrou, M.et al., Identification of the growth-hormone-releasing peptide-2 (GHRP-2) in a nutritional supplement, Drug Test.Anal., 2010, 2, 144-148

[10] Thomas A., Höppner, S., Geyer, H., Schänzer, W., Petrou, M., Kwiatkowska, D.et al., Determination of growth hormone releasing peptides (GHRP) and their major metabolites in human urine for doping controls by means of liquid chromatography mass spectrometry, Anal Bioanal Chem., 2011, 401, 507-516

[11] Thevis M., Mass Spectrometry in Sports Drug Testing: Characterization of Prohibited Substances and Doping Control Analytical Assays., 2010, 49

[12] Henninge J., Pepaj, M., Hullstein, I., Hemmersbach, P., Identification of CJC-1295, a growth-hormone-releasing peptide, in an unknown pharmaceutical preparation, Drug Test Analysis., 2010, 2, 647-650
[13] Mock S., Shen, X., Tamvakopoulos, C., Determination of melanotan-II in rat plasma by liquid chromatography/tandem mass spectrometry: determination of pharmacokinetic parameters in rat following intravenous administration, Rapid Commun.Mass Spectrom., 2002, 16, 2142-2147

[14] Tamvakopoulos C., Mass spectrometry for the quantification of bioactive peptides in biological fluids, Mass Spectrom.Rev., 2007, 26, 389-402

[15] Hatziieremia S., Kostomitsopoulos, N., Balafas, V., Tamvakopoulos, C., A liquid chromatographic/tandem mass spectroscopic method for quantification of the cyclic peptide melanotan-II. Plasma and brain tissue concentrations following administration in mice, Rapid Commun.Mass Spectrom., 2007, 21, 2431-2438

[16] Popot M. A., Woolfitt, A. R., Garcia, P., Tabet, J. C., Determination of IGF-I in horse plasma by LC electrospray ionisation mass spectrometry, Anal Bioanal Chem., 2008, 390, 1843-1852

[17] Kay R., Halsall, D. J., Annamalai, A. K., Kandasamy, N., Taylor, K., Fenwick, S.et al., A novel mass spectrometry-based method for determining insulin-like growth factor 1: assessment in a cohort of subjects with newly diagnosed acromegaly, Clin Endocrinol., 2013, 78, 424-430

[18] Bredehöft M., Schänzer, W., Thevis, M., Quantification of human insulin-like growth factor-1 and qualitative detection of its analogues in plasma using liquid chromatography/electrospray ionisation tandem mass spectrometry, Rapid Commun.Mass Spectrom., 2008, 22, 477-485

[19] Thevis M., Bredehöft, M., Kohler, M., Schänzer, W., Mass Spectrometry-Based Analysis of IGF-1 and hGH., 2010, 195, 201-207

[20] Gam L. H., Tham, S. Y., Latiff, A., Immunoaffinity extraction and tandem mass spectrometric analysis of human chorionic gonadotropin in doping analysis, Journal of Chromatography B., 2003, 792, 187-196

[21] Liu C. and Bowers, L. D., Mass spectrometric characterization of the beta-subunit of human chorionic gonadotropin, J.Mass Spectrom., 1997, 32, 33-42

[22] Morten Bødskov., Forslag til lov om ændring af straffeloven., L 8, 2-10-2013, http://www.ft.dk/Rlpdf/samling/20131/lovforslag/L8/20131_L8_som_vedtaget. pd 